\title{
AKTA PRZEWODÓW DOKTORSKICH I HABILITACYJNYCH Z ZAKRESU NAUK HISTORYCZNYCH I SPOLECZNYCH WYDZIALU TEOLOGICZNEGO ATK
}

W Archiwum Uniwersytetu Kardynała Stefana Wyszyńskiego w Warszawie, obejmującym zespół złożony, akt Akademii Teologii Katolickiej w Warszawie (ATK) z lat 1954-1999 oraz Uniwersytetu Kardynała Stefana Wyszyńskiego w Warszawie (UKSW), znaczną grupę akt o wartości historycznej stanowią akta przewodów doktorskich i habilitacyjnych ${ }^{1}$. W niniejszym opracowaniu źródłowym przedstawiono akta przewodów doktorskich i habilitacyjnych, powstałych na Wydziale Teologicznym ATK i obejmujących dyscypliny z zakresu nauk historycznych i społecznych. Wchodzą tu w grę: historia Kościoła, historia sztuki kościelnej, patrologia, archeologia chrześcijańska, muzykologia, a także socjologia religii i związane z nią katolicka nauka społeczna i etyka społeczna ${ }^{2}$. Na bazie tych dyscyplin utworzono w 1987 r. Wydział Kościelnych Nauk Historycznych i Społecznych. Stąd też przewody doktorskie i habilitacyjne z zakresu tych nauk, przeprowadzane na Wydziale Teologicznym, zamykają się w okresie 19541987. Akta przewodów otworzonych i niezakończonych przed wyodrębnieniem się Wydziału Kościelnych Nauk Historycznych i Społecznych przekazano temuż wydziałowi i nie stanowią w tym miejscu przedmiotu naszego zainteresowania ${ }^{3}$.

*Dariusz Milewski - dr hab. historii, adiunkt w Instytucie Nauk Historycznych UKSW w Warszawie, e-mail: d.milewski@uksw.edu.pl

${ }^{1}$ Organizacja i działanie Archiwum UKSW zostały przedstawione w: D. Milewski, Pierwsze lata Archiwum Uniwersytetu Kardynała Stefana Wyszyńskiego w Warszawie-organizacja i funkcjonowanie. „Archiwa Biblioteki i Muzea Kościelne”, 93 (2010) s. 153-161.

${ }^{2}$ Początki i dzieje poszczególnych kierunków historycznych na Wydziale Teologicznym ATK w pierwszym dwudziestoleciu działania uczelni omówili: E. Wyczawski, Historia Kościoła, w: XX lat Akademii Teologii Katolickiej. Księga pamiatkowa 1954-1974, red. E. Wyczawski, Warszawa 1976, s. 128-148; E. Stanula, Patrologia, tamże, s. 148-162; J. Pasierb, Historia sztuki kościelnej, tamże, s. 162-173,T. Gołgowski, Archeologia starochrześcijańska, tamże, s. 173-180.

${ }^{3}$ Zostały one przedstawione w opracowaniu: D. Milewski, Akta przewodów doktorskich i habilitacyjnych Wydziału Kościelnych Nauk Historycznych i Spotecznych ATK, „Archiwa, Biblioteki i Muzea Kościelne”, 96 (2011) s. 39-56 
Obecne opracowanie ma za zadanie przedstawienie akt przewodów doktorskich i habilitacyjnych z zakresu nauk historycznych i społecznych Wydziału Teologicznego ATK z lat 1954-1987. Tym samym ma stanowić materiał źródłowy do badań nad dziejami tych dyscyplin na Wydziale Teologicznym i ułatwić badania nad historią późniejszych Wydziałów: Kościelnych Nauk Historycznych i Społecznych na ATK (1987-1999) i Nauk Historycznych i Społecznych na UKSW (od 1999 r.).

Wydział Teologiczny ATK, powstały na bazie Wydziału Teologii Katolickiej Uniwersytetu Warszawskiego, przejął prawa do nadawania stopnia doktora w zakresie teologii - w tym również $\mathrm{w}$ zakresie dyscyplin historycznych. Pierwsze nowo otwarte przewody doktorskie datują się na jesień 1955 r. (np. doktoraty Władysława Celmerowskiego czy Jerzego Mrówczyńskiego). Mamy też przypadek kontynuacji przewodu, rozpoczętego na Uniwersytecie Warszawskim - chodzi o nostryfikację dyplomu doktorskiego Adama Wojtyły (notabene niezakończoną). Ogółem liczba akt przewodów doktorskich z zakresu nauk historycznych i społecznych Wydziału Teologicznego ATK, znajdujących się w Archiwum UKSW, wynosi 69. Mniejszy jest zasób aktowy przewodów habilitacyjnych - tylko 14 jednostek archiwalnych. Trzeba jednak zauważyć, że akta te datują się dopiero od 1967 r., a i tak ich liczba jest zawsze mniejsza od liczby akt przewodów doktorskich $^{4}$. W skład jednostki archiwalnej zarówno akt przewodów doktorskich, jak i habilitacyjnych, wchodzą akta przewodu, począwszy od podania do Rady Wydziału o otwarcie przewodu doktorskiego bądź habilitacyjnego, a skończywszy na odpisie do akt dyplomu bądź zaświadczeniu o nostryfikacji dyplomu. Czasami z reguły w najstarszych aktach - brak jest odpisu dyplomu do akt i teczkę zamyka akt przysięgi doktorskiej sponsio sollemnis. Integralną częścią akt jest praca doktorska lub habilitacyjna - jej ewentualny brak w aktach zawsze odnotowano. Akta znajdują się w odpowiednio opisanych i opatrzonych sygnaturami teczkach. Akta doktorskie zostały już opracowane i spaginowane.

Jak już wspomniano, akta przewodów doktorskich z zakresu nauk historycznych i społecznych Wydziału Teologicznego ATK w Archiwum UKSW liczą 69 jednostek archiwalnych. Są to akta przewodów otwartych i zakończonych na Wydziale, jak i akta nostryfikacji dyplomów doktorskich, uzyskanych na uczelniach zagranicznych. Tylko w jednym przypadku - nostryfikacji dyplomu doktorskiego A. Wojtyły - mamy do czynienia z niezakończonym przewodem doktorskim. Pozostałe akta tego typu nie zostały przekazane przez Wydział Teologiczny do Archiwum UKSW. Łącznie akta doktorskie obejmują lata 1951-1987 (większość dokumentacji dotyczącej nostryfikacji dyplomu A. Wojtyły są to de facto anteriora, wytworzone jeszcze na Wydziale Teologii Katolickiej UW). Cała dokumentacja akt przewodów doktorskich Wydziału Teologicznego znalazła się w posiadaniu Archiwum w chwili jego powstania i brakuje dla niej spisów zdawczo-odbiorczych. Całość dokumentacji przedstawiono w tabeli $\mathrm{nr}$ 1, sporządzonej według wzoru, przyjętego wcześniej w opracowaniu dotyczącym akt przewodów dok-

${ }^{4}$ Pierwsze doktoraty i habilitacje z zakresu historii omówił w skrócie E. Wyczawski, Historia Kościoła, s. 131-132,134-135. Doktoraty z zakresu patrologii przedstawił E. Stanula, Patrologia, s. 150, zaś z zakresu historii sztuki kościelnej J. Pasierb, Historia sztuki kościelnej, s. 164. 
torskich Wydziału Kościelnych Nauk Historycznych i Społecznych ATK. Akta $\mathrm{w}$ tabeli uszeregowano zgodnie $\mathrm{z}$ ich tymczasowymi sygnaturami, według przeprowadzonego w Archiwum porządkowania i opracowania.

Tabela akt przewodów doktorskich obejmuje osiem kolumn. Kolumna pierwsza ma charakter porządkowy. W kolumnie drugiej zaznaczono tymczasową sygnaturę akt. W kolejnej kolumnie (nr 3) podano nazwisko doktoranta. Kolumna 4. zawiera temat pracy, liczbę stron dla każdego tomu pracy oraz - w razie konieczności - liczbę ilustracji. Temat pracy pochodzi ze strony tytułowej $\mathrm{w}$ razie braku pracy w aktach, temat zaczerpnięto z akt przewodu. W kolumnie 5 . podano specjalność, $\mathrm{w}$ jakiej nadany został stopień doktora - zgodnie z urzędowym zawiadomieniem o nadaniu stopnia doktora, znajdującym się w aktach. W kolumnie 6. podano nazwisko promotora - bądź promotorów, jeśli w trakcie przewodu nastąpiła zmiana ${ }^{5}$. W przypadku nostryfikacji odnotowano ten fakt właśnie w tej kolumnie. W kolumnie 7. podano nazwiska recenzentów. Kolumna 8. obejmuje cztery informacje: datę otwarcia przewodu doktorskiego, datę obrony pracy, datę uchwały Rady Wydziału o nadaniu stopnia doktora oraz datę i numer dyplomu doktorskiego (według księgi dyplomów doktorskich, znak BK-532) . $^{6}$. W przypadku nostryfikacji wpisywano numer zaświadczenia zamiast numeru kolejnego z księgi dyplomów doktorskich. Brak w kolumnie 8. którejś z dat oznacza, iż odnośnego aktu nie znaleziono w teczce bądź też - co następuje w przypadku przerwania przewodu doktorskiego - nie doszło do powstania danego $\mathrm{aktu}^{7}$. W przypadku trzech doktoratów, jeśli brak jest odpisu dyplomu do akt, podano datę z aktu przysięgi doktorskiej, oznaczając ten fakt informacją [sponsio sollemnis] ${ }^{8}$.

Podobnie skonstruowano tabelę, prezentującą akta przewodów habilitacyjnych Wydziału Teologicznego ATK z zakresu nauk historycznych i społecznych, przechowywanych w Archiwum UKSW ${ }^{9}$. Ponieważ wszystkie akta habilitacyj-

${ }^{5} \mathrm{~W}$ jednym przypadku - akt przewodu doktorskiego A. Grabowskiego - odnotowano również, iż promotor pracował poza ATK (był nim prof. Stanisław Herbst z UW).

${ }^{6}$ Księga dyplomów doktorskich jest ciągle w użyciu i pozostaje w gestii Działu Kształcenia UKSW, stąd podajemy znak akt.

${ }^{7} \mathrm{~W}$ kilku przypadkach, nawet $\mathrm{w}$ razie braku odpowiednich akt, odnaleziono ich daty na podstawie protokołów z posiedzeń Rady Wydziału Teologicznego. Dotyczy to przede wszystkim otwarcia przewodów doktorskich: S. Grada (Protokoły z posiedzeń Rady Wydziału Teologicznego, AUKSW, sygn. WT/16, s. 17), M. Grzybowskiego (Protokoły z posiedzeń Rady Wydziału Teologicznego, AUKSW, sygn. WT/17, s. 27), Z. Pawłowskiego (Protokoły z posiedzeń Rady Wydziału Teologicznego, AUKSW, sygn. WT/18, s. 3), S. Makarewicza (tamże, s. 3), J. Słomińskiej (tamże, s. 20), B. Micewskiego (Protokoły z posiedzeń Rady Wydziału Teologicznego, AUKSW, sygn. WT/25, s. 15) i A. Dylus (Protokoły z posiedzeń Rady Wydziału Teologicznego, AUKSW, sygn. WT/31, s. 29). Niepewna jest data otwarcia przewodu doktorskiego W. Kujawskiego - w aktach przewodu znaleziono jedynie datę roczną 1973, podaną w urzędowym zawiadomieniu o nadaniu stopnia doktora. Nie znajduje ona jednak potwierdzenia w odnośnych Protokołach z posiedzeń Rady Wydziału Teologicznego, AUKSW, sygn. WT/20. Dlatego przy tej dacie postawiono znak zapytania.

${ }^{8}$ Są to akta J. Pasierba, W. Celmerowskiego i W. Zwierza.

${ }^{9}$ Również i w tym przypadku skopiowano schemat tabeli akt przewodów habilitacyjnych WKNHiS z wcześniejszego opracowania (zob. przypis 3). 
ne Wydziału Teologicznego ATK znalazły się w posiadaniu Archiwum w chwili jego powstania, nie ma dla nich spisów zdawczo-odbiorczych. Akta opatrzono zatem sygnaturami tymczasowymi. Całość dokumentacji obejmuje 14 jednostek archiwalnych z lat 1967-1987. Tabela, prezentująca tę dokumentację, składa się z siedmiu kolumn - pierwszej porządkowej i sześciu tematycznych. W kolumnie 2. podano sygnaturę akt, zaś w kolumnie 3 . nazwisko habilitanta. Kolumna 4. podaje temat pracy oraz liczbę stron (ówczesne prace nie były jeszcze wydawane drukiem). W kolumnie 5. zaznaczono specjalność, w jakiej nadany został stopień doktora habilitowanego, a w kolumnie 6. podano nazwiska recenzentów pracy habilitacyjnej (z reguły trzy osoby). Kolumna 7. zawiera cztery informacje: 1) datę otwarcia przewodu habilitacyjnego, 2) datę kolokwium habilitacyjnego i uchwały Rady Wydziału o nadaniu stopnia doktora habilitowanego (odbywało się to tego samego dnia), 3) datę pisma Centralnej Komisji Kwalifikacyjnej do Spraw Kadr Naukowych przy Prezesie Rady Ministrów, zatwierdzającego uchwałę Rady Wydziału o nadaniu stopnia doktora habilitowanego ${ }^{10}$ oraz 4) datę i numer dyplomu doktora habilitowanego. W przypadku numeru dyplomu stosowano na Wydziale praktykę analogiczną do numerowania dyplomów doktorskich.

Akta przewodów habilitacyjnych wymagają kilku słów wyjaśnienia. Podobnie jak w przypadku akt przewodów doktorskich, do Archiwum UKSW przekazano w zasadzie tylko akta przewodów zakończonych. Zdarza się, że brakuje akt przewodów niezakończonych, o których możemy powziąć wiadomości na podstawie protokołów Rady Wydziału Teologicznego ${ }^{11}$. Ponadto, według E. Wyczawskiego, jako pierwszy habilitował się na Wydziale Teologicznym ATK z zakresu historii

${ }^{10} \mathrm{Na}$ mocy art. 11, pkt 2, ust. 1 Ustawy z dnia 31 marca 1965 r. o stopniach naukowych i tytułach naukowych zatwierdzanie uchwały Rady Wydziału o nadaniu stopnia doktora habilitowanego należało do ministra sprawującego nadzór nad szkołą wyższą. Przekazanie uprawnień w tej sprawie przez Ministerstwo Nauki, Szkolnictwa Wyższego i Techniki Centralnej Komisji Kwalifikacyjnej do Spraw Kadr Naukowych przy Prezesie Rady Ministrów nastąpiło na mocy nowelizacji ww. Ustawy, dokonanej w 1973 r. (art. 11, pkt 2 Obwieszczenia Ministra Nauki, Szkolnictwa Wyższego i Techniki z dnia 10 lipca 1973 r. w sprawie ogłoszenia jednolitego tekstu ustawy z dnia 31 marca 1965 r. o stopniach naukowych i tytułach naukowych, Dz. U. 1973, nr 32, poz. 192). Ponieważ jednak w zachowanych aktach nie ma odpowiedzi Ministra na odpowiednie wnioski, kierowane przez rektora ATK i dziekana Wydziału Teologicznego, a są dopiero pisma z Centralnej Komisji - począwszy od habilitacji J. Kusia - podano w tabeli informację tylko o zatwierdzaniu uchwał Rady Wydziału przez Centralną Komisję, które faktycznie znajdują się w aktach.

${ }^{11}$ Brakuje np. w Archiwum UKSW akt przewodu habilitacyjnego Witolda Pietkuna, który chciał zakończyć habilitację, podjętą jeszcze na Wydziale Teologii Katolickiej UW i dla którego Rada Wydziału Teologicznego ATK powołała 22 I 1964 r. komisję do oceny jego dorobku - Protokoły z posiedzeń Rady Wydziału Teologicznego, AUKSW, sygn. WT/11, s. 1. Na posiedzeniu w dniu 24 VI 1964 r. stwierdzono, że „sprawa habilitacji ks. dr-a Pietkuna uległa zwłoce” - tamże, s. 15. Jednak już 6 X 1964 r. przyjęto recenzje i dopuszczono W. Pietkuna do kolokwium habilitacyjnego (tamże, s. 18). Następnie doszło do jakiegoś sporu między W. Pietkunem a Radą Wydziału odnośnie jego habilitacji - czego ślady znajdujemy w aktach posiedzeń 4 XI 1964 r. i 16 XII 1964 r. (tamże, s. 24 i 26), po czym sprawa habilitacji W. Pietkuna powoli znika z akt posiedzeń Rady Wydziału Teologicznego (jest jeszcze komunikat dziekana na posiedzeniu 6 X 1965 r. - Protokoły z posiedzeń Rady Wydziału Teologicznego, AUKSW, sygn. WT/12, s. 24). 
Kościoła ks. Henryk Rybus na podstawie pracy Prymas Maciej Drzewicki. Zarys biografii 1467-1535 $5^{12}$. Akt tego przewodu nie ma jednak w Archiwum UKSW. Można go odtworzyć na podstawie innej dokumentacji. W teczce osobowej H. Rybusa, przechowywanej w Archiwum UKSW, znajdujemy m.in. sprawozdanie, w którym H. Rybus informuje o wydrukowaniu swej pracy habilitacyjnej w „Studia Theologica Varsaviensia”, 2 (1964) s. 79-308 ${ }^{13}$. Z życiorysu, napisanego 19 marca 1970 r., wynika, iż przewód habilitacyjny odbył się 27 maja 1964 r., a 3 czerwca tegoż roku, po wykładzie habilitacyjnym, Rada Wydziału Teologicznego nadała $\mathrm{H}$. Rybusowi stopień docenta teologii w zakresie historii Kościoła ${ }^{14}$. Departament Studiów Uniwersyteckich i Ekonomicznych Ministerstwa Szkolnictwa Wyższego w piśmie z 5 stycznia 1966 r. stwierdził w odniesieniu do H. Rybusa, że

uchwała Rady Wydziału Teologicznego zapadła przed wydrukowaniem pracy habilitacyjnej jest nieważna i wymaga powtórzenia ${ }^{15}$.

W ślad za tym Rada Wydziału Teologicznego 19 stycznia 1966 r. ponowiła swoją uchwałę o nadaniu stopnia docenta H. Rybusowi, a 21 stycznia rektor ATK, ks. prof. Józef Iwanicki wysłał odnośne protokoły do Ministerstwa Szkolnictwa Wyższego ${ }^{16}$. Ostatecznie Minister Szkolnictwa Wyższego, Henryk Jabłoński, pismem z dnia 29 kwietnia 1966 r. zatwierdził uchwałę Rady Wydziału Teologicznego z dnia 19 stycznia tego roku o nadaniu H. Rybusowi stopnia naukowego docenta teologii w zakresie historii Kościoła ${ }^{17}$.

Ważne informacje w tej sprawie odnajdziemy także w protokołach z posiedzeń Rady Wydziału Teologicznego ATK, przechowywanych w Archiwum UKSW. Jak z nich wynika, Rada Wydziału na wniosek komisji powołanej do rozpatrzenia podania H. Rybusa o dopuszczenie go do przewodu habilitacyjnego podjęła pozytywną uchwałę i powołała komisję do oceny dorobku naukowego H. Rybusa w dniu 22 stycznia 1964 r. ${ }^{18}$ Na posiedzeniu w dniu 20 maja 1964 r. Rada Wydziału Teologicznego uchwaliła dopuścić H. Rybusa do kolokwium habilitacyjnego i wyznaczyła jego datę na 27 maja tegoż roku ${ }^{19}$. Brakuje jednak w tych aktach protokołów z kolokwium habilitacyjnego 27 maja i nadania H. Rybusowi stopnia docenta 3 czerwca, o czym wiemy skądinąd ${ }^{20}$. Zachowała się natomiast uchwała

${ }^{12}$ Habilitacja nastąpiła w 1964 r., a recenzentami byli: Eugeniusz Wyczawski, Marian Rechowicz i Jadwiga Karwasińska - E. Wyczawski, Historia Kościoła, s. 131.

${ }^{13}$ Akta osobowe Henryka Rybusa, Archiwum UKSW, sygn. DK-I/671 - H. Rybus, Sprawozdanie z całorocznej działalności katedry Historii Kościoła Powszechnego przy ATK w Warszawie za r. szk. 1964/65, Łódź 18 VI 1965 r. (strony niepaginowane).

${ }^{14}$ Tamże.

${ }^{15}$ Tamże. Pismo nosi znak DUE-II-3-162/65.

16 Tamże.

${ }^{17}$ Tamże. Pismo ministra o znaku DUE-II-3-162/65 zarejestrowano w ATK pod numerem R-4a$103 / 66$.

${ }^{18}$ Protokoły z posiedzeń Rady Wydziału Teologicznego, AUKSW, sygn. WT/11, s. 1.

19 Tamże, s. 20.

${ }^{20}$ Dla porównania, w protokołach posiedzeń Rady Wydziału Teologicznego zachowały się analogiczne akta z przewodu habilitacyjnego ks. Jerzego Nosowskiego - zob. Protokoły z posiedzeń 
z 19 stycznia 1966 r. o nadaniu H. Rybusowi stopnia docenta w zakresie historii Kościoła - aczkolwiek na podstawie samych akt posiedzeń Rady Wydziału Teologicznego nie umielibyśmy odpowiedzieć, dlaczego stało się to tak późno ${ }^{21}$. Ponieważ niniejszy wykaz dotyczy tylko akt przewodów doktorskich i habilitacyjnych, które są w Archiwum UKSW, pominięto w nim habilitację H. Rybusa. Przedstawiliśmy jednak tę sprawę tutaj, gdyż naświetla ona pewne braki w zachowanych aktach i pozwala na zachowanie krytycyzmu w korzystaniu z nich i traktowaniu jako jedynego źródła do dziejów przewodów doktorskich i habilitacyjnych z zakresu nauk historycznych na Wydziale Teologicznym ATK.

Jeden z pierwszych przewodów, L. Stefaniuka, został otworzony na Wydziale Historycznym Uniwersytetu Warszawskiego 9 stycznia 1968 r. Rada Wydziału Historycznego UW odrzuciła jednak 1 lipca 1968 r. wniosek komisji o dopuszczenie L. Stefaniuka do kolokwium habilitacyjnego, co zaowocowało poprawieniem pracy przez habilitanta i ponownym przedstawieniem jej Radzie Wydziału 1 kwietnia 1969 r. Rada Wydziału, nie mogąc zdecydować się na jednoznaczną ocenę pracy, zwróciła się 6 maja 1969 r. o wyjaśnienie do Ministra Oświaty i Szkolnictwa Wyższego. Tamże odwołał się sam L. Stefaniuk pismem z dnia 7 czerwca 1969 r. W odpowiedzi z dnia 26 listopada 1969 r., Minister Oświaty i Szkolnictwa Wyższego przeniósł przewód habilitacyjny L. Stefaniuka do Akademii Teologii Katolickiej. Rada Wydziału Teologicznego ATK podjęła sprawę, uchwalając 22 stycznia 1970 r. dopuszczenie L. Stefaniuka do kolokwium habilitacyjnego. Całość akt tego przewodu znalazła się w posiadaniu ATK i trafiła do Archiwum UKSW. Dlatego też, z uwagi na ciągłość sprawy i zachowanie dokumentacji wraz $\mathrm{z}$ anteriorami $\mathrm{w}$ aktach, przechowywanych $\mathrm{w}$ Archiwum UKSW, zdecydowano się przyjąc jako początek przewodu datę jego otworzenia na Wydziale Historycznym UW i zaznaczyć ten fakt w tabeli.

Ciekawie przedstawia się również sprawa habilitacji W. Urbana. Otworzył on przewód habilitacyjny na Wydziale Teologicznym Uniwersytetu Jagiellońskiego w 1949 r. i tamże odbył kolokwium habilitacyjne w dniu 26 lutego 1953 r. Rada Wydziału Teologicznego UJ nadała wtedy W. Urbanowi veniam legendi, nie otrzymał on jednak dyplomu doktora. W dniu 16 grudnia 1970 r. Rada Wydziału Teologicznego ATK, w związku z potrzebą zatrudnienia W. Urbana, podjęła sprawę nadania mu stopnia doktora habilitowanego ${ }^{22}$. Ponieważ jednak z Uniwersytetu Jagiellońskiego nie przekazano żadnych akt, dotyczących przewodu habilitacyjnego W. Urbana, a Rada Wydziału Teologicznego ATK opierała się głównie na zeznaniach świadków tamtego przewodu i opiniach ówczesnych recenzentów W. Urbana, w niniejszym opracowaniu przyjęto za datę otworzenia przewodu habilitacyjnego dzień 16 grudnia 1970 r., a więc oficjalne podjęcie sprawy przez Wydział Teologiczny ATK. Zdecydował o tym zarówno brak anteriorów w aktach, przechowywanych w Archiwum UKSW, jak też fakt ponownego powołania

Rady Wydziału Teologicznego, AUKSW, sygn. WT/12, s. 29-31 (posiedzenie w dniu 27 X 1965 r.).

${ }^{21}$ Protokoły z posiedzeń Rady Wydziału Teologicznego, AUKSW, sygn. WT/13, s. 4.

${ }^{22}$ Opracowujący dzieje Wydziału Teologicznego E. Wyczawski, op. cit., s. 131, stwierdził: „Jego [W. Urbana - D.M.] krakowska habilitacja z 1953 r. została sfinalizowana w Akademii w 1971 r. i zatwierdzona przez Ministerstwo". 
recenzentów i odbycia kolokwium habilitacyjnego w dniu 16 lutego 1971 r. przed Radą Wydziału Teologicznego ATK.

Wreszcie, jeśli chodzi o przewód habilitacyjny F. Stopniaka, trzeba wyjaśnić, że w pierwszym przypadku zakończył się on niepowodzeniem - praca Kościół na Lubelszczyźnie i Podlasiu na przełomie XIX i XX wieku pomimo iż przyjęta przez Radę Wydziału Teologicznego ATK, nie uzyskała zatwierdzenia Centralnej Komisji Kwalifikacyjnej do Spraw Kadr Naukowych. Habilitant po czterech latach, w 1977 r., otworzył nowy przewód na podstawie innej pracy - Franciszek Jaczewski biskup lubelski - i tym razem doczekał się szczęśliwego wyniku. Mamy tu więc do czynienia $\mathrm{z}$ dwoma przewodami habilitacyjnymi tej samej osoby, a zatem i dwiema jednostkami archiwalnymi.

Przedstawiony materiał źródłowy ma zobrazować rodzenie się i rozwój dyscyplin historycznych i społecznych na Wydziale Teologicznym ATK, co prawda w pewnym tylko, ale istotnym aspekcie, jakim było kształcenie własnej kadry naukowej poprzez nadawanie stopni doktora i doktora habilitowanego. W tej mierze materiał ten uzupełnia poprzednie wydanie, dotyczące akt doktorskich i habilitacyjnych Wydziału Kościelnych Nauk Historycznych i Społecznych ATK. Uważny czytelnik dostrzeże zapewne, iż wielu doktorów, wypromowanych na Wydziale Teologicznym ATK, habilitowało się później na Wydziale Kościelnych Nauk Historycznych i Społecznych, a i samych doktorów i doktorów habilitowanych Wydziału Teologicznego spotykamy później wśród promotorów i recenzentów prac doktorskich i recenzentów prac habilitacyjnych Wydziału Kościelnych Nauk Historycznych i Społecznych. Fakt ten unaocznia zatem pewną ciągłość badań historycznych i społecznych w Akademii Teologii Katolickiej - i później w Uniwersytecie Kardynała Stefana Wyszyńskiego. Dzięki temu prezentowany wykaz dokumentacji ma możliwość stać się pomocą i materiałem do badań nie tylko nad zasobem Archiwum UKSW, ale i nad dziejami nauk historycznych i społecznych w ATK i UKSW.

Słowa kluczowe: przewody doktorskie, przewody habilitacyjne, nauki historyczne i społeczne, dokumentacja, Akademia Teologii Katolickiej, Archiwum UKSW 


\begin{tabular}{|c|c|c|c|c|c|c|c|}
\hline 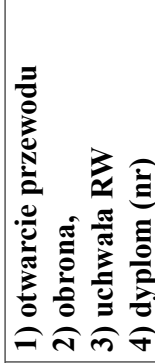 & $\infty$ & 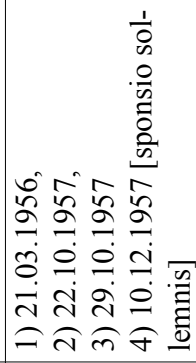 & 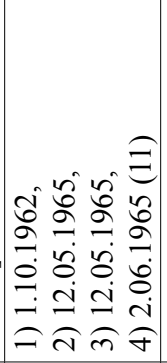 & 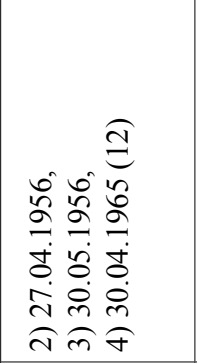 & 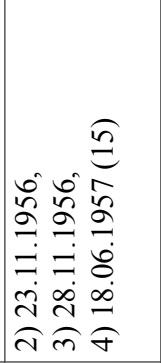 & 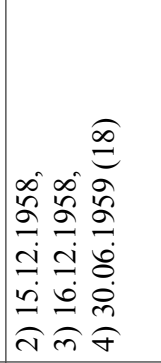 & 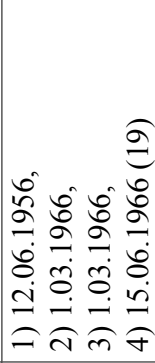 \\
\hline 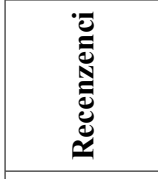 & $r$ & 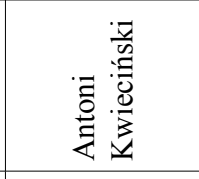 & 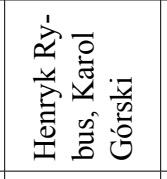 & 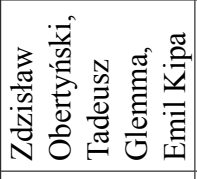 & 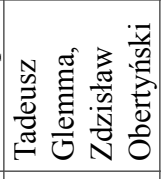 & 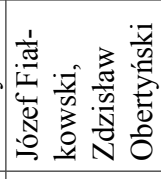 & 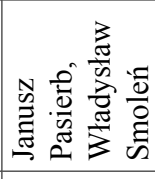 \\
\hline 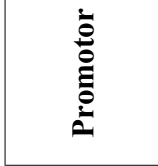 & 0 & 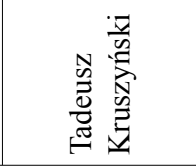 & 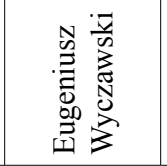 & 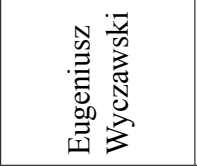 & 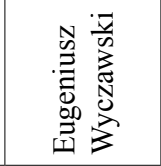 & 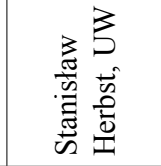 & 荌 \\
\hline 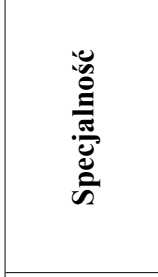 & in & 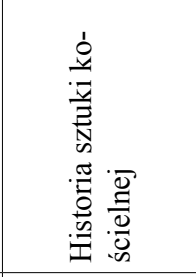 & 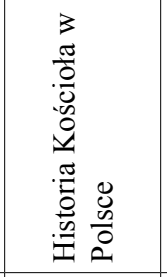 & 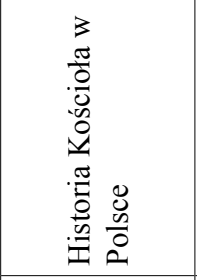 & 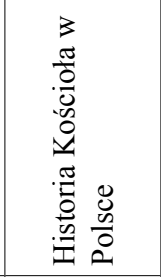 & 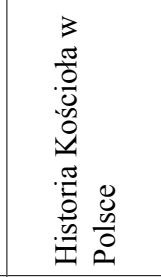 & 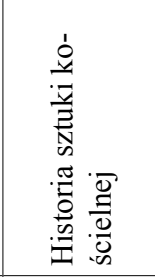 \\
\hline 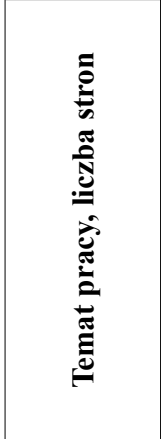 & $\nabla$ & 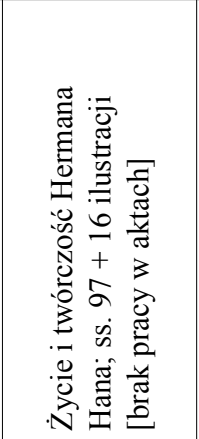 & 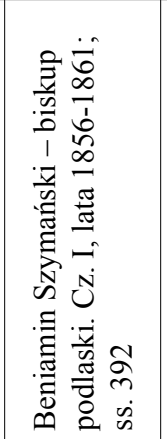 & 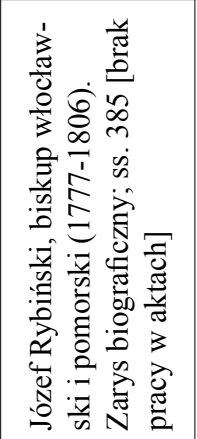 & 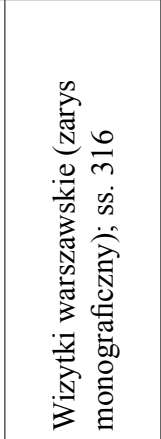 & 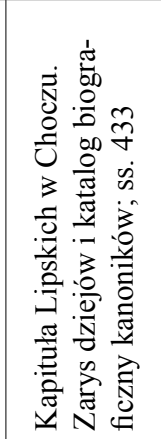 & 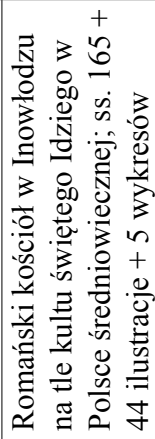 \\
\hline 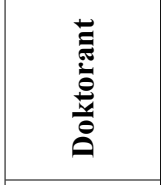 & $m$ & 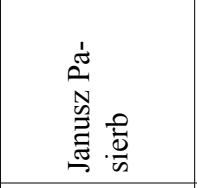 & 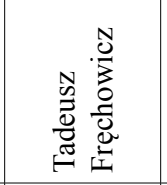 & 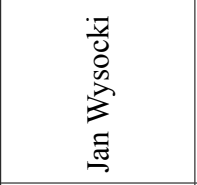 & 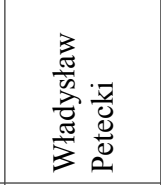 & 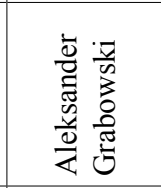 & 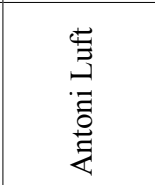 \\
\hline 党恶 & $\boldsymbol{N}$ & 0 & $\infty$ & $a$ & 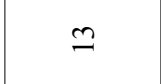 & $\mathscr{0}$ & $\curvearrowright$ \\
\hline$\stackrel{\dot{\leftrightarrow}}{\dot{\leftrightarrow}}$ & -1 & - & $\sim$ & $m$ & $\nabla$ & $n$ & 6 \\
\hline
\end{tabular}




\begin{tabular}{|c|c|c|c|c|c|c|c|}
\hline$\infty$ & 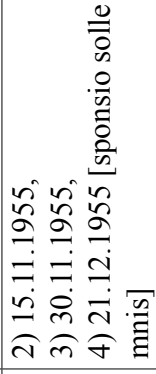 & 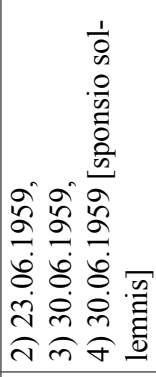 & 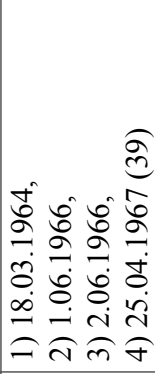 & 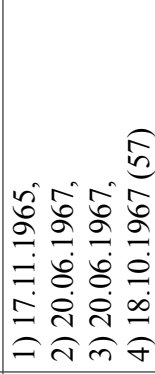 & 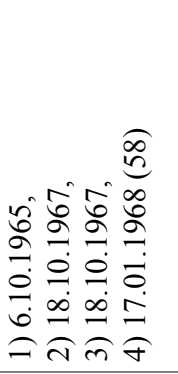 & 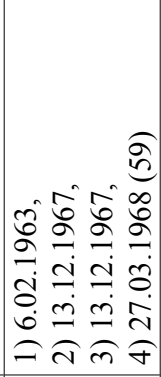 & 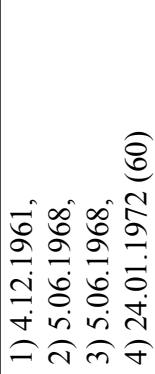 \\
\hline$r$ & 苞 & 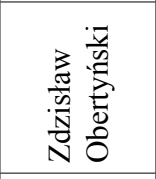 & 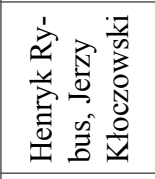 & 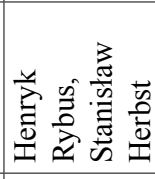 & 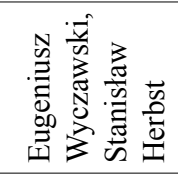 & 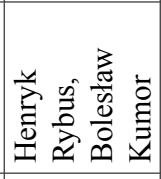 & 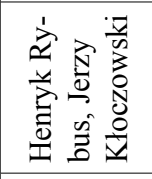 \\
\hline (6) & 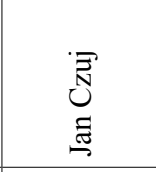 & 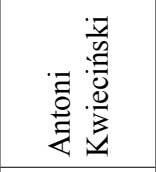 & 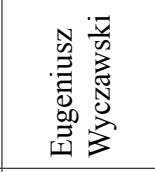 & 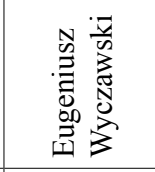 & 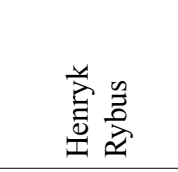 & 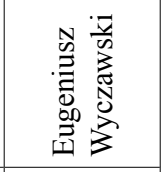 & 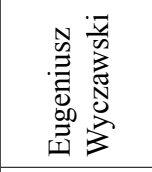 \\
\hline in & 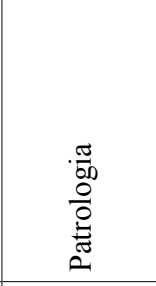 & 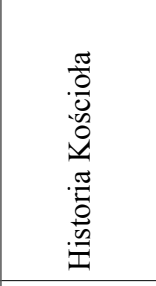 & 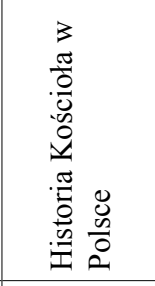 & $\begin{array}{l}\frac{\pi}{0} \\
.0 \\
00 \\
0 \\
1 \\
\cdot \frac{\pi}{0} \\
0 \\
: 0\end{array}$ & 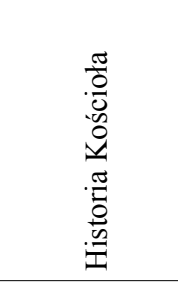 & $\begin{array}{l}\frac{\pi}{0} \\
\cdot 0 \\
0 \\
0 \\
1 \\
\cdot \frac{\pi}{0} \\
0 \\
0 \\
0\end{array}$ & 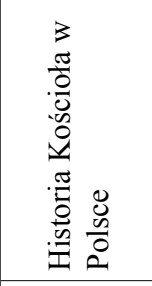 \\
\hline$\nabla$ & 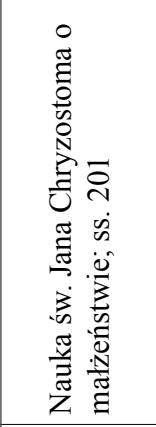 & 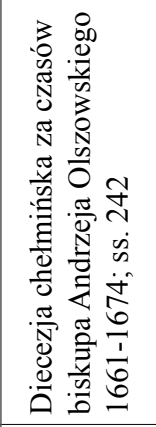 & 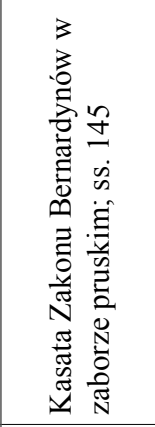 & 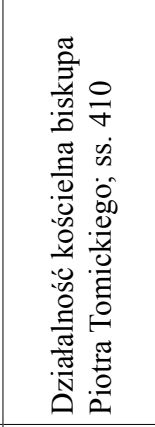 & 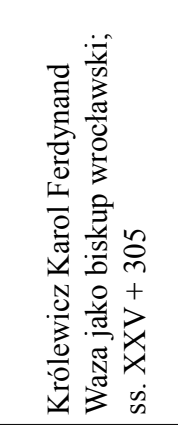 & 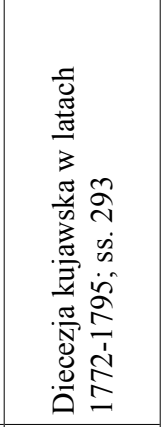 & 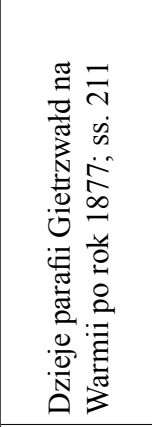 \\
\hline$m$ & 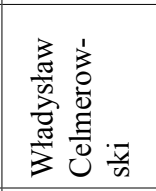 & 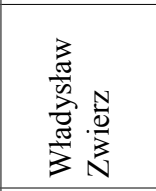 & 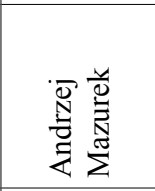 & 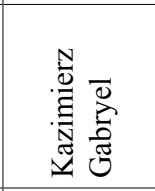 & 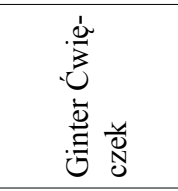 & 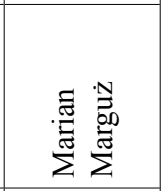 & 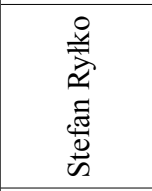 \\
\hline $\mathbf{N}$ & $\stackrel{\sim}{\sim}$ & $m$ & ભે & $\stackrel{\vartheta}{\forall}$ & $\forall$ & $\stackrel{n}{+}$ & \& \\
\hline- & $r$ & $\infty$ & $a$ & $ㅇ$ & $=$ & $\simeq$ & - \\
\hline
\end{tabular}




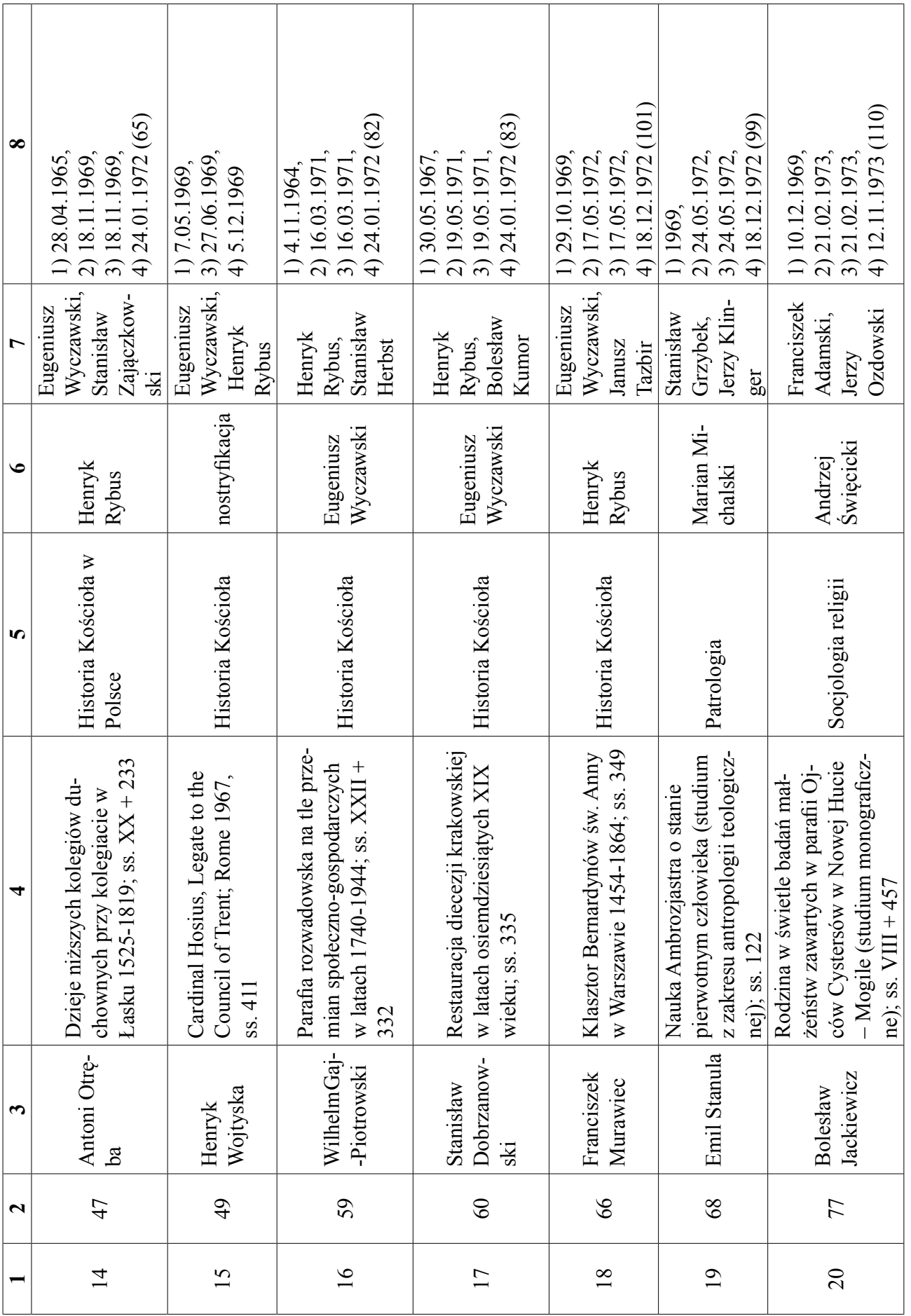




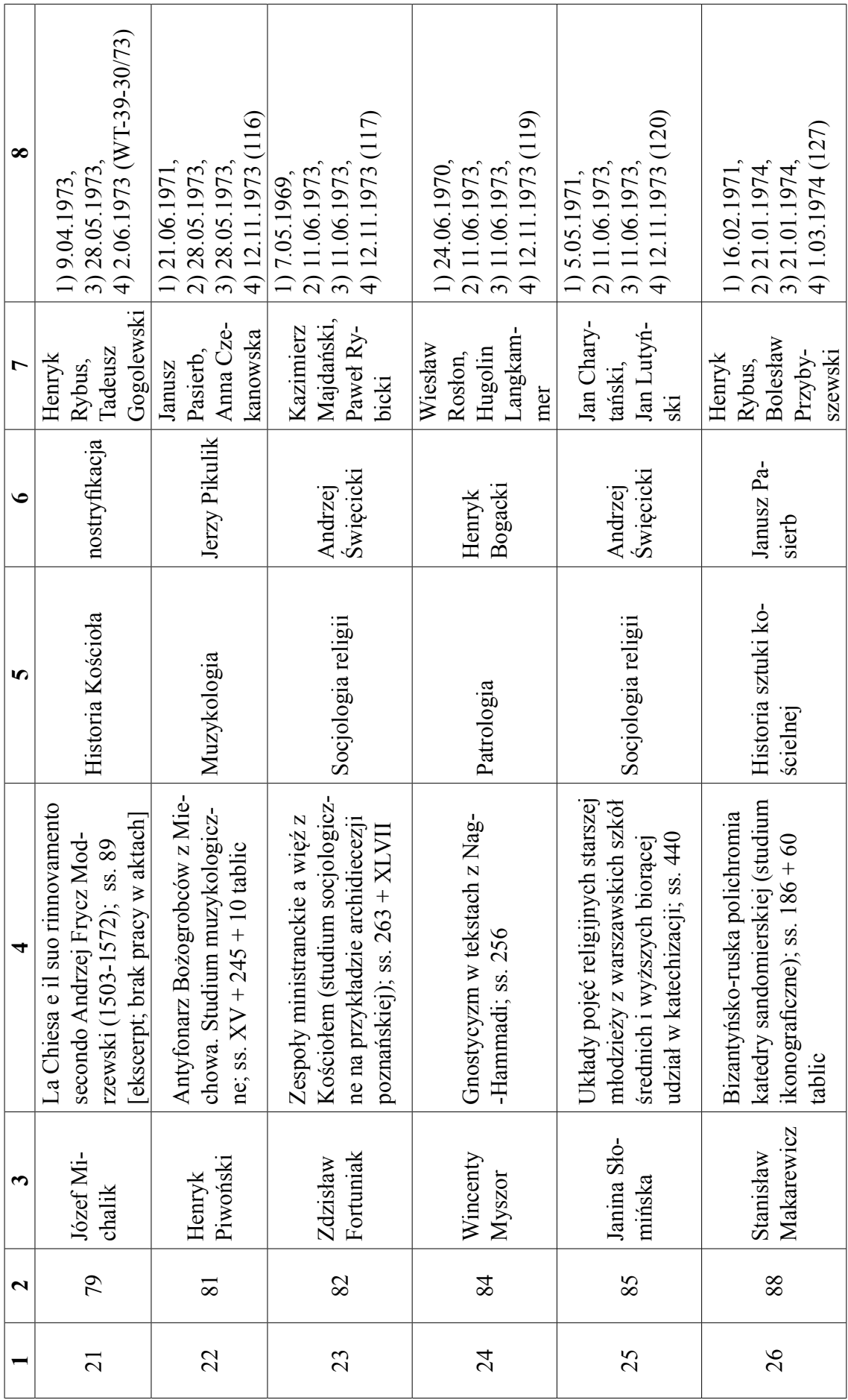




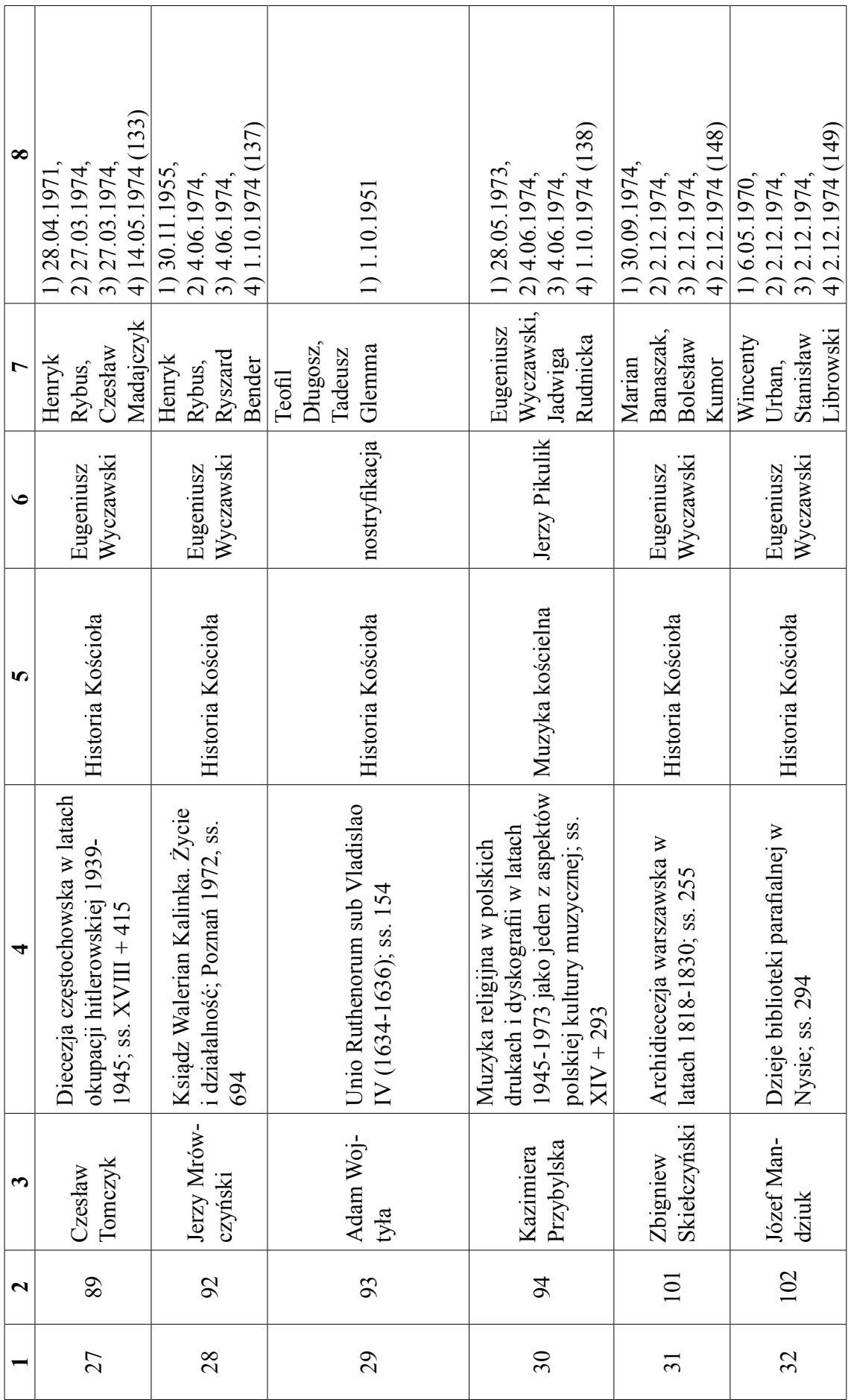




\begin{tabular}{|c|c|c|c|c|c|c|c|}
\hline$\infty$ & 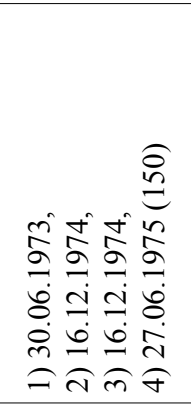 & 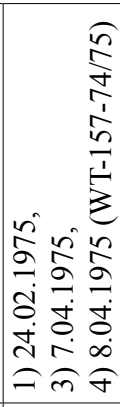 & 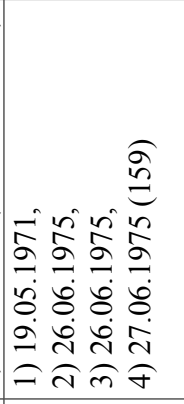 & 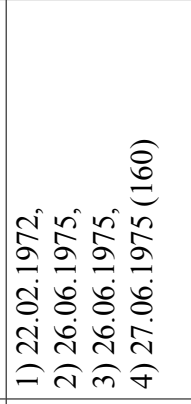 & 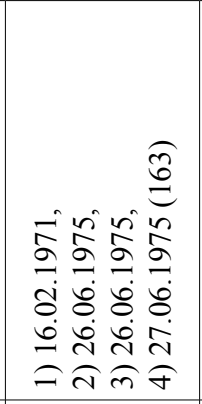 & 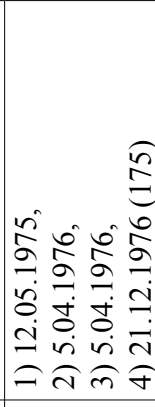 & 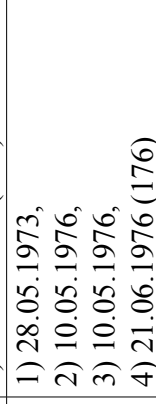 \\
\hline$r$ & 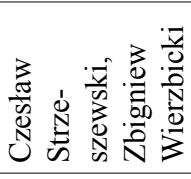 & 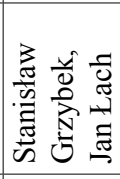 & 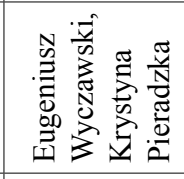 & 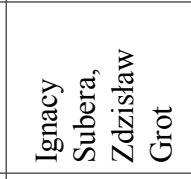 & 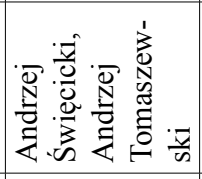 & 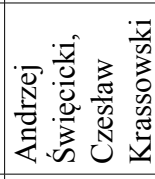 & 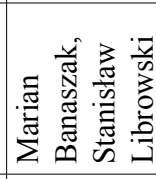 \\
\hline 0 & 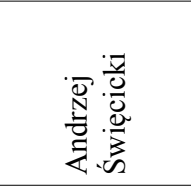 & 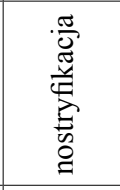 & 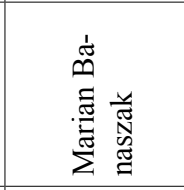 & 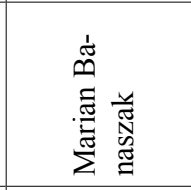 & 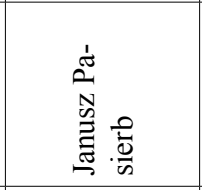 & 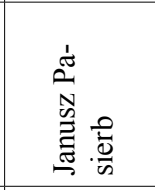 & 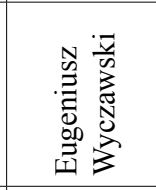 \\
\hline in & 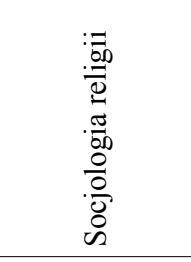 & $\begin{array}{l}\frac{\pi}{00} \\
\frac{0}{0} \\
0 \\
0 \\
0 \\
0\end{array}$ & 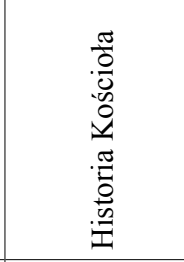 & 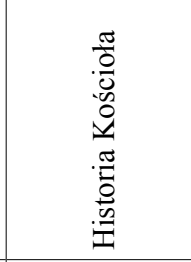 & 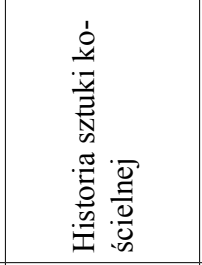 & 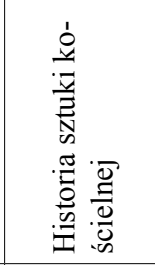 & 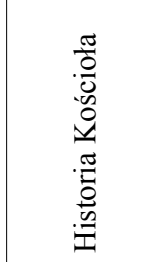 \\
\hline$\nabla$ & 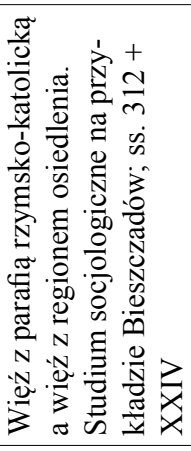 & 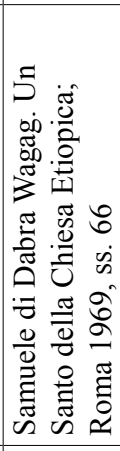 & 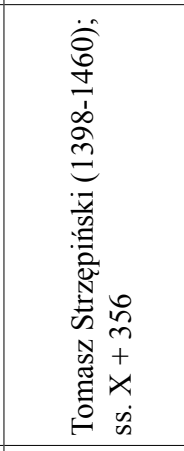 & 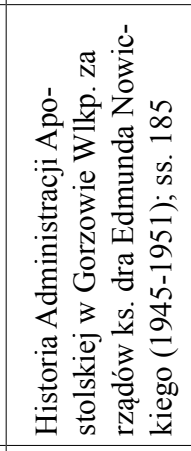 & 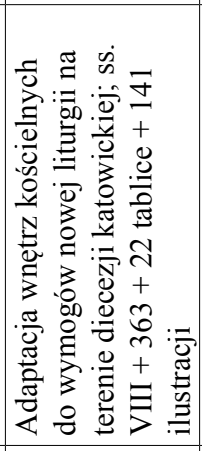 & 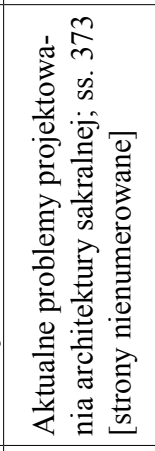 & 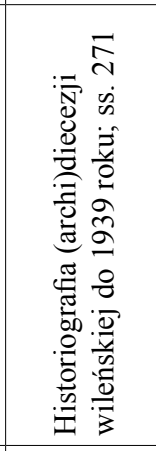 \\
\hline$m$ & 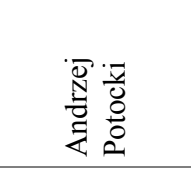 & 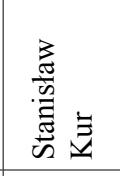 & 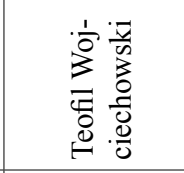 & 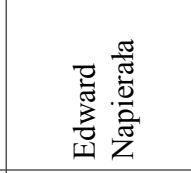 & 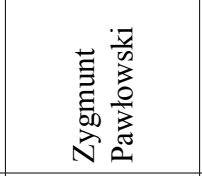 & $\frac{\pi}{\frac{\pi}{0}} \frac{\tilde{d}}{\frac{D}{0}}$ & 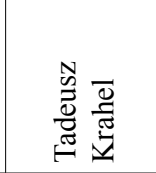 \\
\hline$N$ & $\stackrel{0}{0}$ & $\hat{\sigma}$ & $\stackrel{\infty}{\circ}$ & $\stackrel{1}{0}$ & $\stackrel{\beth}{\Xi}$ & $\equiv$ & $\stackrel{\infty}{=}$ \\
\hline 7 & $\tilde{m}$ & m & $\ddot{m}$ & ల & $\hat{n}$ & $\stackrel{\infty}{\infty}$ & ले \\
\hline
\end{tabular}




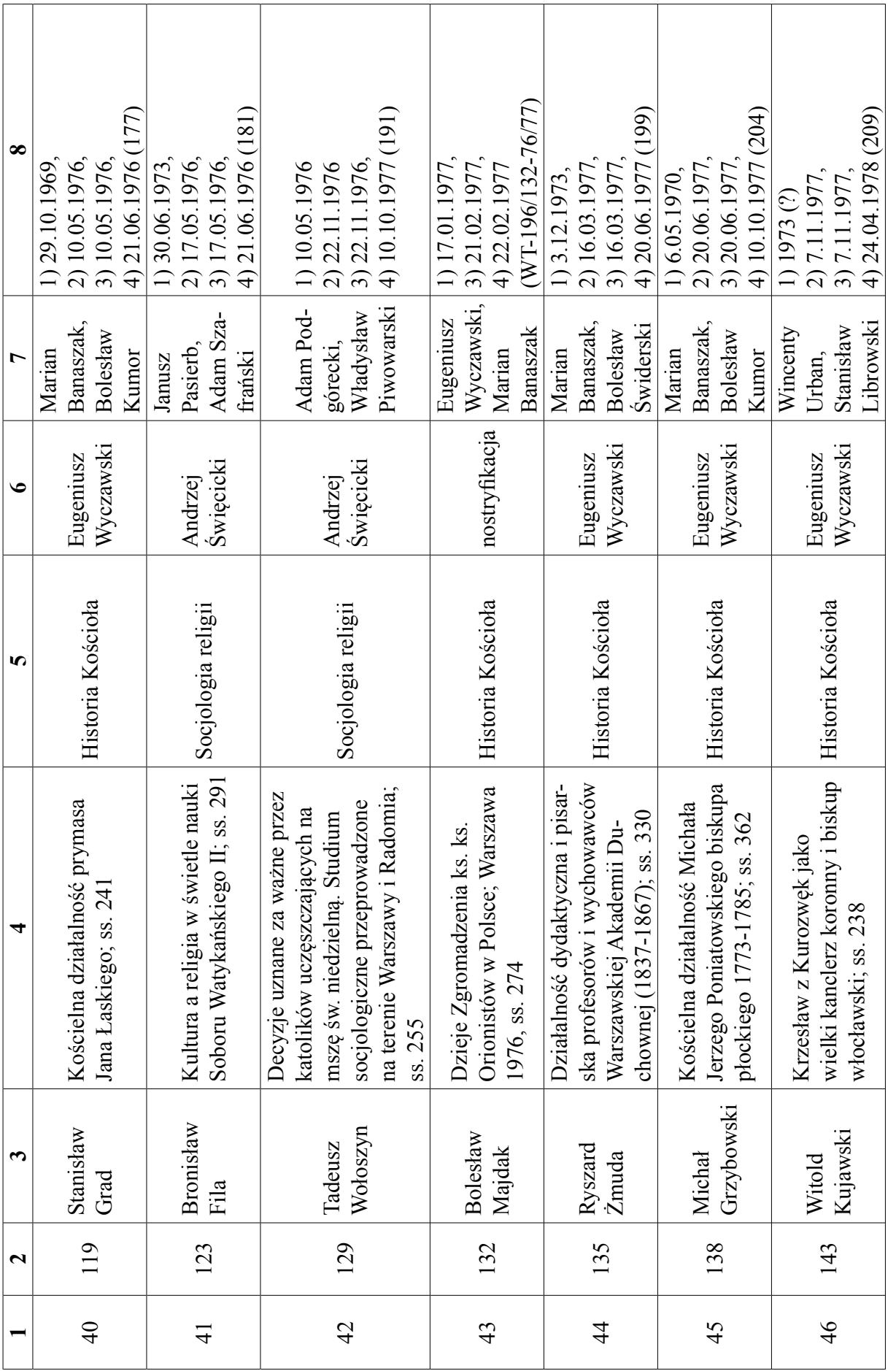




\begin{tabular}{|c|c|c|c|c|c|}
\hline$\infty$ & 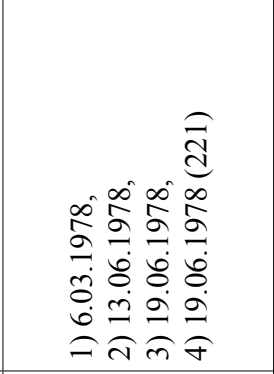 & 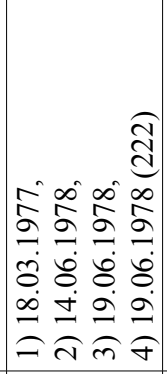 & 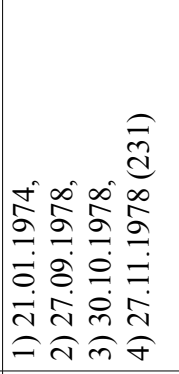 & 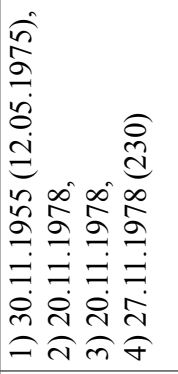 & 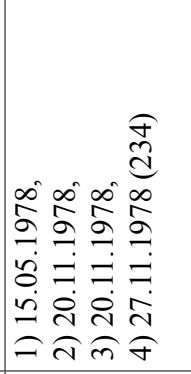 \\
\hline$r$ & 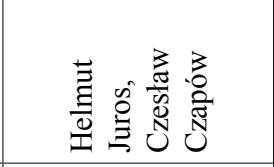 & 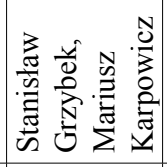 & 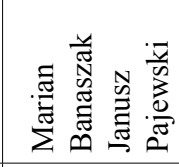 & 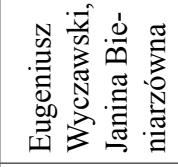 & 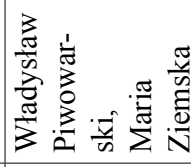 \\
\hline 0 & 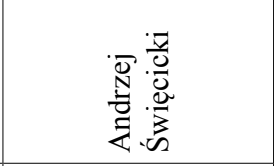 & 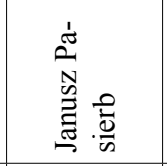 & 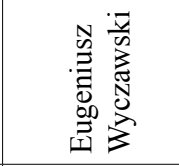 & 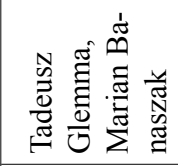 & 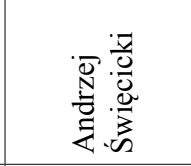 \\
\hline$n$ & 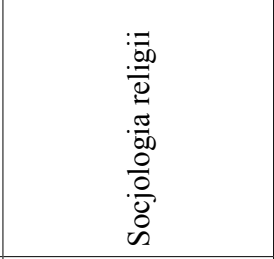 & 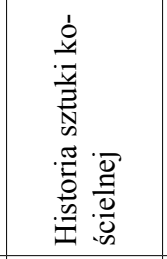 & 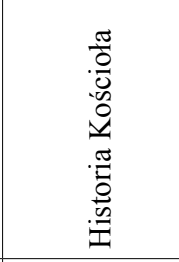 & 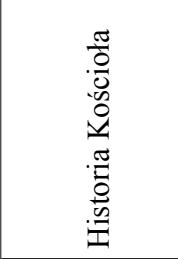 & 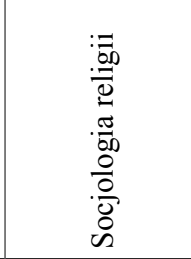 \\
\hline$\nabla$ & 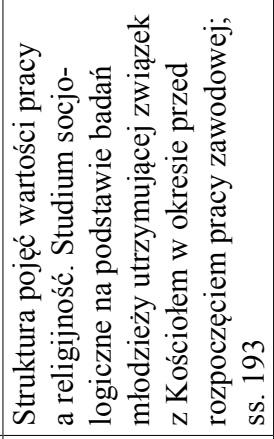 & 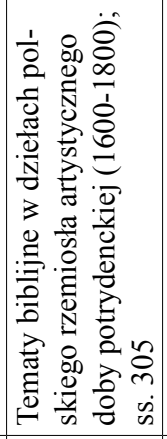 & 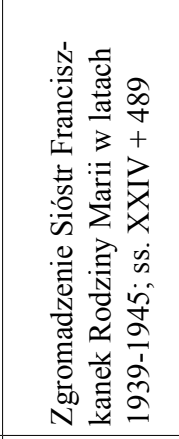 & 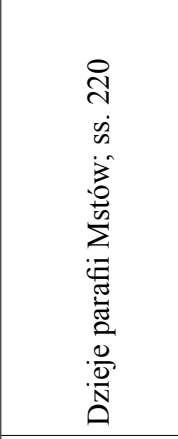 & 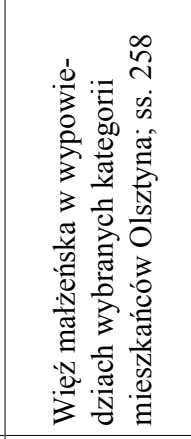 \\
\hline$m$ & 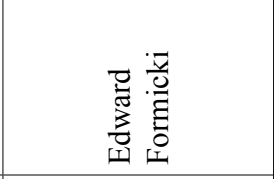 & 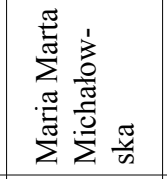 & 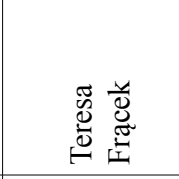 & 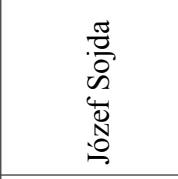 & 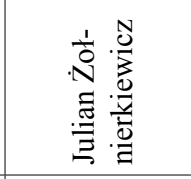 \\
\hline$N$ & $\bar{n}$ & $\stackrel{\sim}{n}$ & $\hat{n}$ & $\stackrel{\infty}{n}$ & $\stackrel{8}{\circ}$ \\
\hline- & 学 & $\stackrel{\infty}{+}$ & gे & in & $\vec{n}$ \\
\hline
\end{tabular}




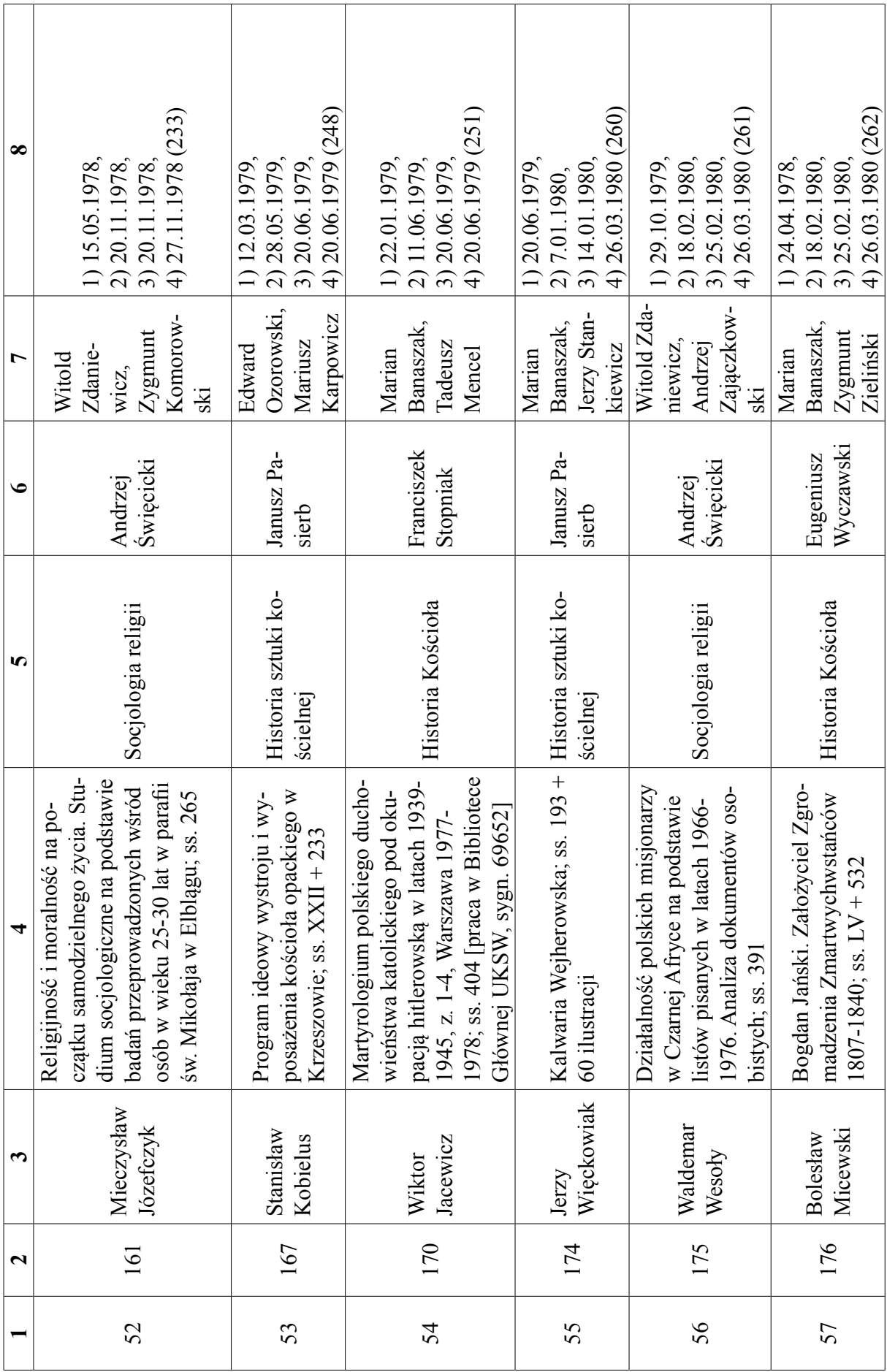




\begin{tabular}{|c|c|c|c|c|c|c|c|}
\hline$\infty$ & 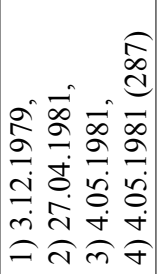 & 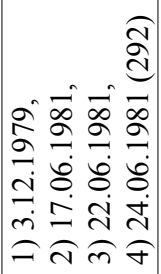 & 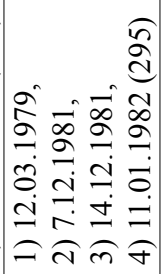 & 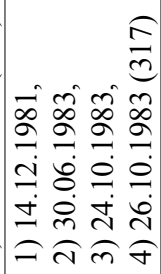 & 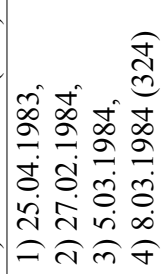 & 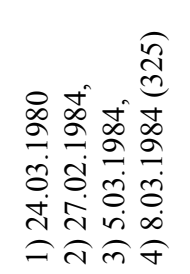 & 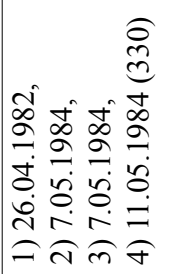 \\
\hline$r$ & 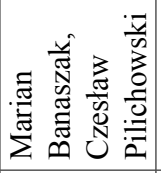 & 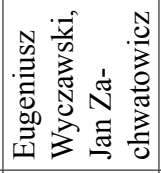 & 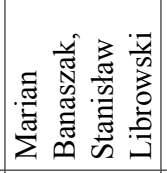 & 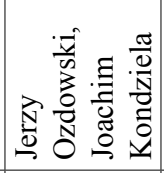 & 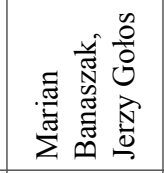 & 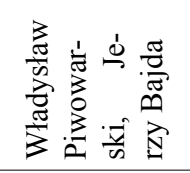 & 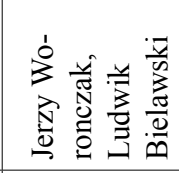 \\
\hline 0 & 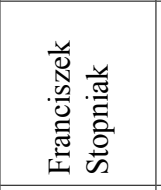 & 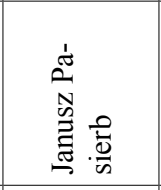 & 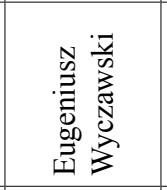 & 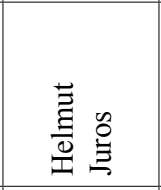 & 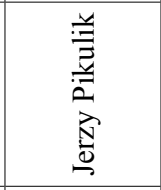 & 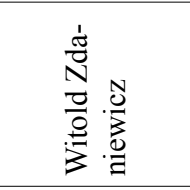 & 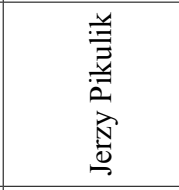 \\
\hline in & $\begin{array}{l}\frac{\pi}{0} \\
\frac{0}{0} \\
0 \\
0 \\
1 \\
\cdot \frac{\pi}{0} \\
0 \\
0 \\
0 \\
0\end{array}$ & 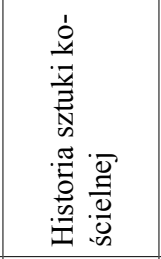 & $\begin{array}{l}\frac{\pi}{0} \\
\frac{0}{0} \\
0 \\
0 \\
1 \\
\cdot \frac{\pi}{0} \\
0 \\
.00 \\
0\end{array}$ & 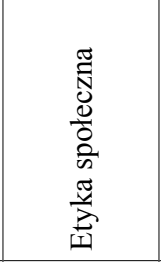 & 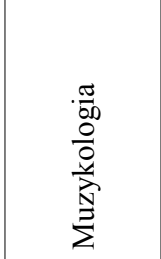 & 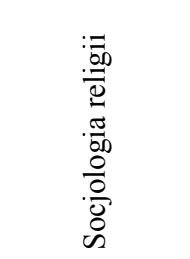 & 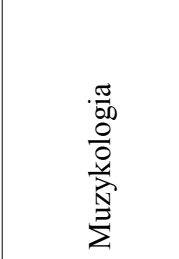 \\
\hline$\nabla$ & 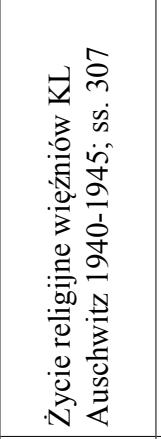 & 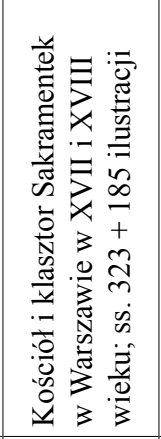 & 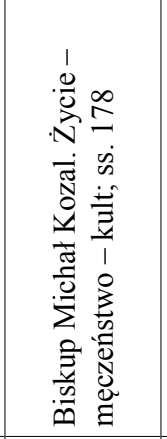 & 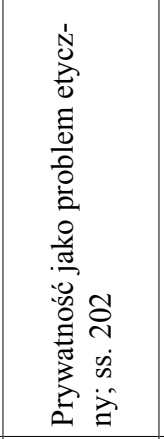 & 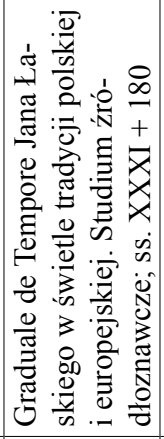 & 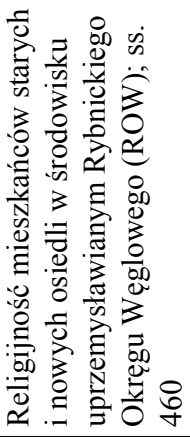 & 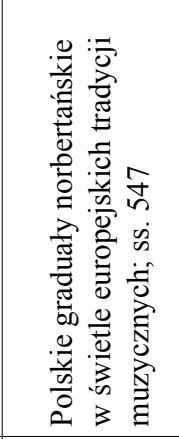 \\
\hline$\infty$ & 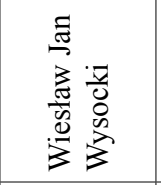 & 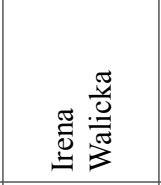 & $\begin{array}{l}\frac{0}{0} \text { 步 } \\
\frac{0}{0} \\
\frac{0}{0} \\
\text { 荧 }\end{array}$ & 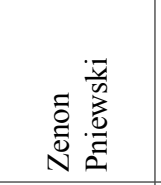 & 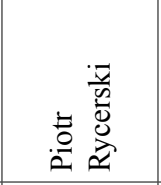 & 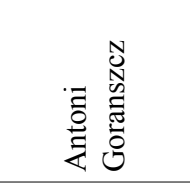 & $\frac{\frac{\pi}{0}}{\sqrt[3]{0}}$ \\
\hline$\sim$ & むே & $\stackrel{\infty}{2}$ & $\underset{\text { ¿ }}{\stackrel{\text { }}{ }}$ & $\bar{\sim}$ & $\overrightarrow{\widetilde{N}}$ & & 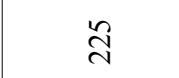 \\
\hline-1 & $\stackrel{\infty}{n}$ & in & 8 & $\bar{\sigma}$ & $\widetilde{\sigma}$ & 6 & t \\
\hline
\end{tabular}




\begin{tabular}{|c|c|c|c|c|c|}
\hline$\infty$ & 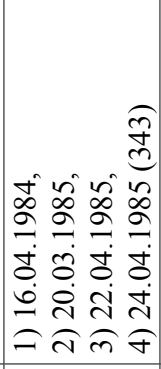 & 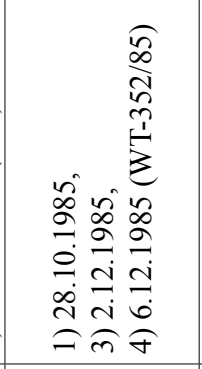 & 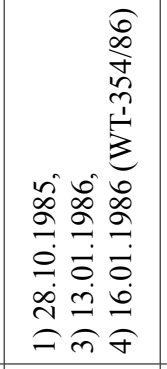 & 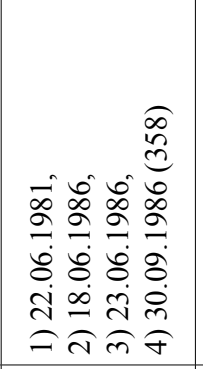 & 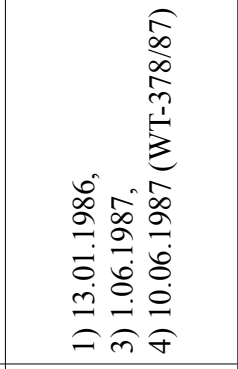 \\
\hline$r$ & 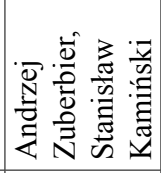 & 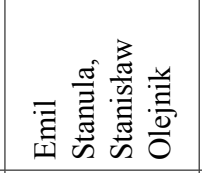 & 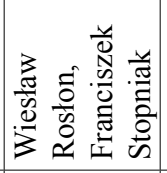 & 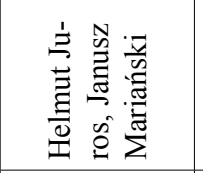 & 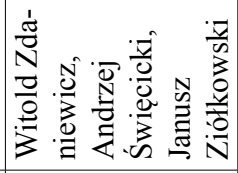 \\
\hline b & 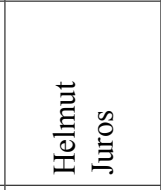 & 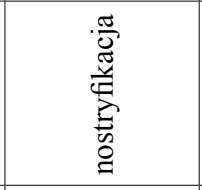 & 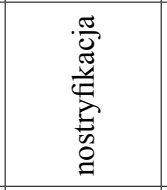 & 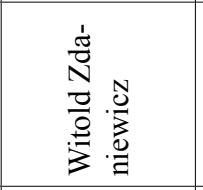 & 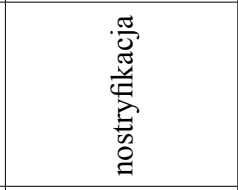 \\
\hline in & 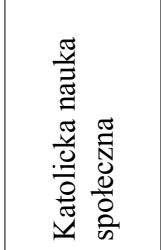 & 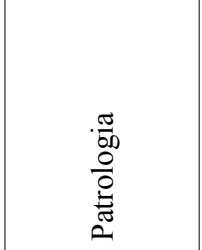 & 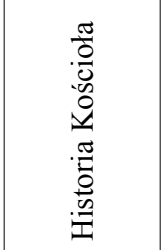 & 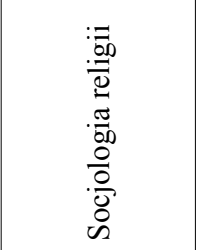 & $\begin{array}{l}\frac{\pi}{60} \\
\frac{0}{0} \\
\frac{0}{8} \\
0 \\
0\end{array}$ \\
\hline$\nabla$ & 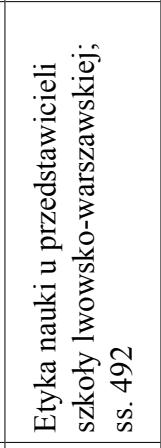 & 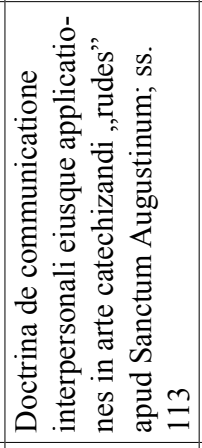 & 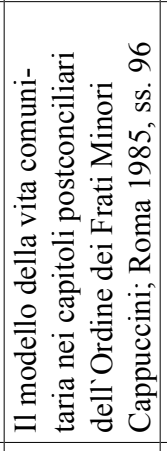 & 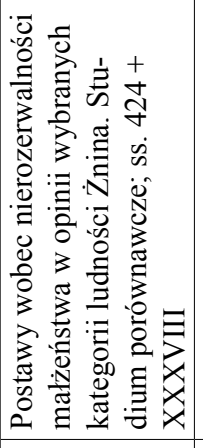 & 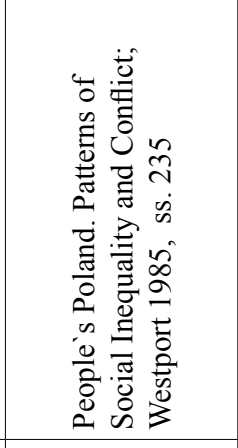 \\
\hline$m$ & $\frac{\frac{\pi}{0}}{3} \frac{n}{\frac{1}{2}}$ & 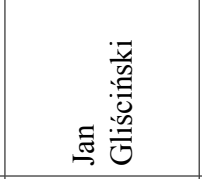 & 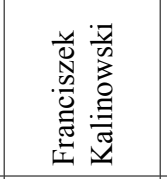 & 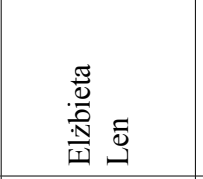 & 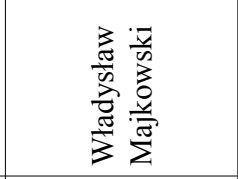 \\
\hline $\boldsymbol{N}$ & $\stackrel{\sim}{\sim}$ & $\stackrel{+}{\sim}$ & $\stackrel{\stackrel{\sim}{\sim}}{ }$ & $\stackrel{+}{\sim}$ & $\stackrel{\infty}{\sim}$ \\
\hline- & 6 & 8 & 6 & $\mathscr{0}$ & જิ \\
\hline
\end{tabular}




\begin{tabular}{|c|c|c|c|c|c|c|}
\hline 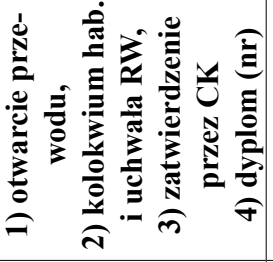 & $r$ & 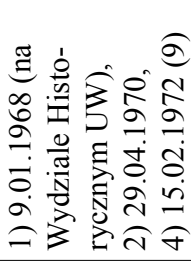 & 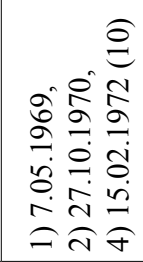 & 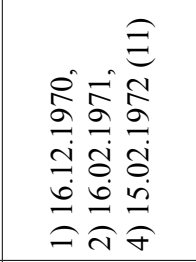 & 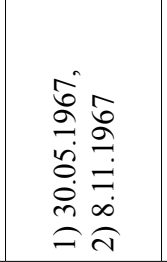 & 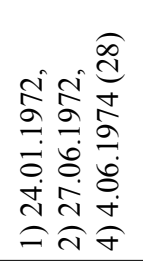 \\
\hline 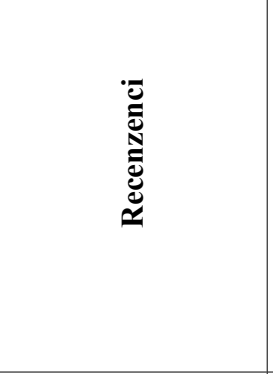 & 0 & 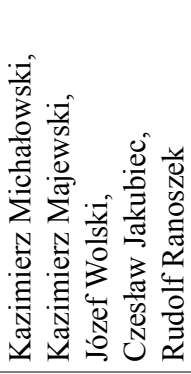 & 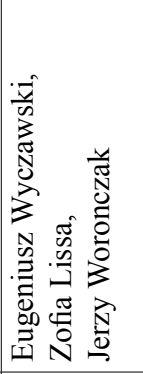 & 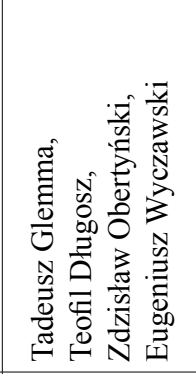 & 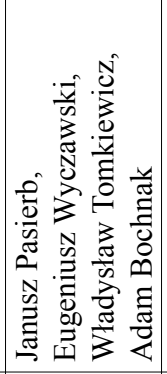 & 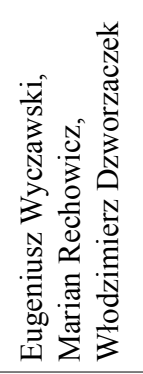 \\
\hline 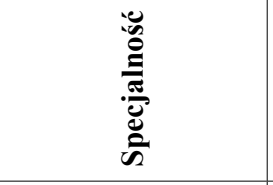 & $n$ & 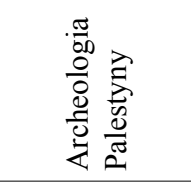 & 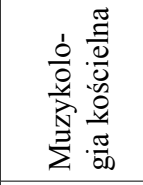 & 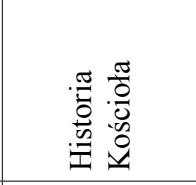 & 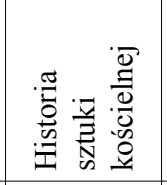 & 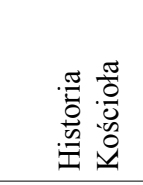 \\
\hline 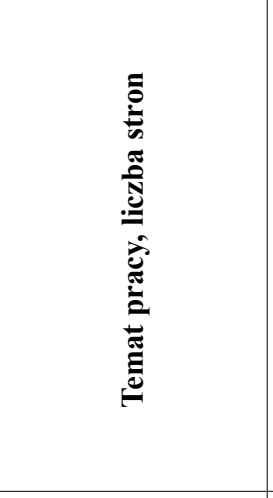 & $\nabla$ & 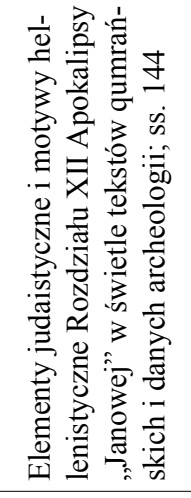 & 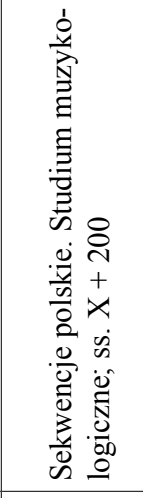 & 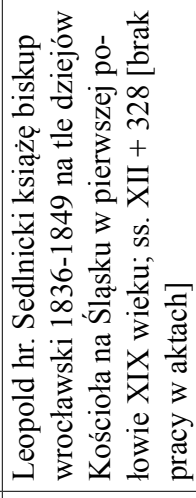 & 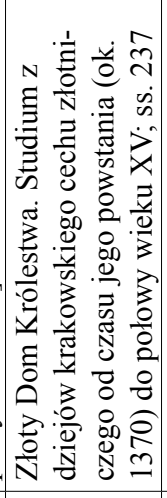 & 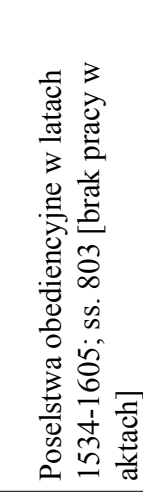 \\
\hline 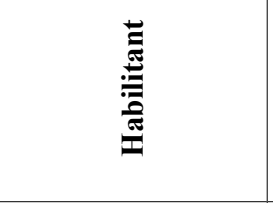 & $m$ & 光壱 & $\begin{array}{l}\text { 总 } \\
\text { 竞 } \\
\end{array}$ & 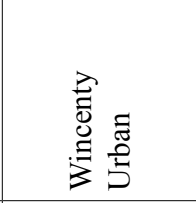 & 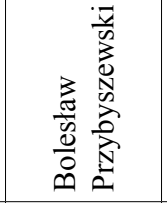 & 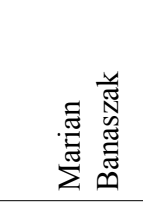 \\
\hline 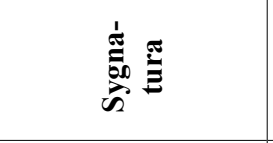 & $\boldsymbol{N}$ & $\begin{array}{c}5 \\
5 \\
1 \\
1 \\
1\end{array}$ & $\begin{array}{l}\infty \\
5 \\
1 \\
1 \\
\end{array}$ & $\begin{array}{l}2 \\
5 \\
1 \\
1 \\
1\end{array}$ & 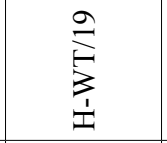 & 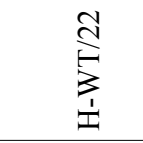 \\
\hline$\stackrel{\dot{\varphi}}{\dot{\varphi}}$ & - & - & $\sim$ & $m$ & $\nabla$ & $n$ \\
\hline
\end{tabular}




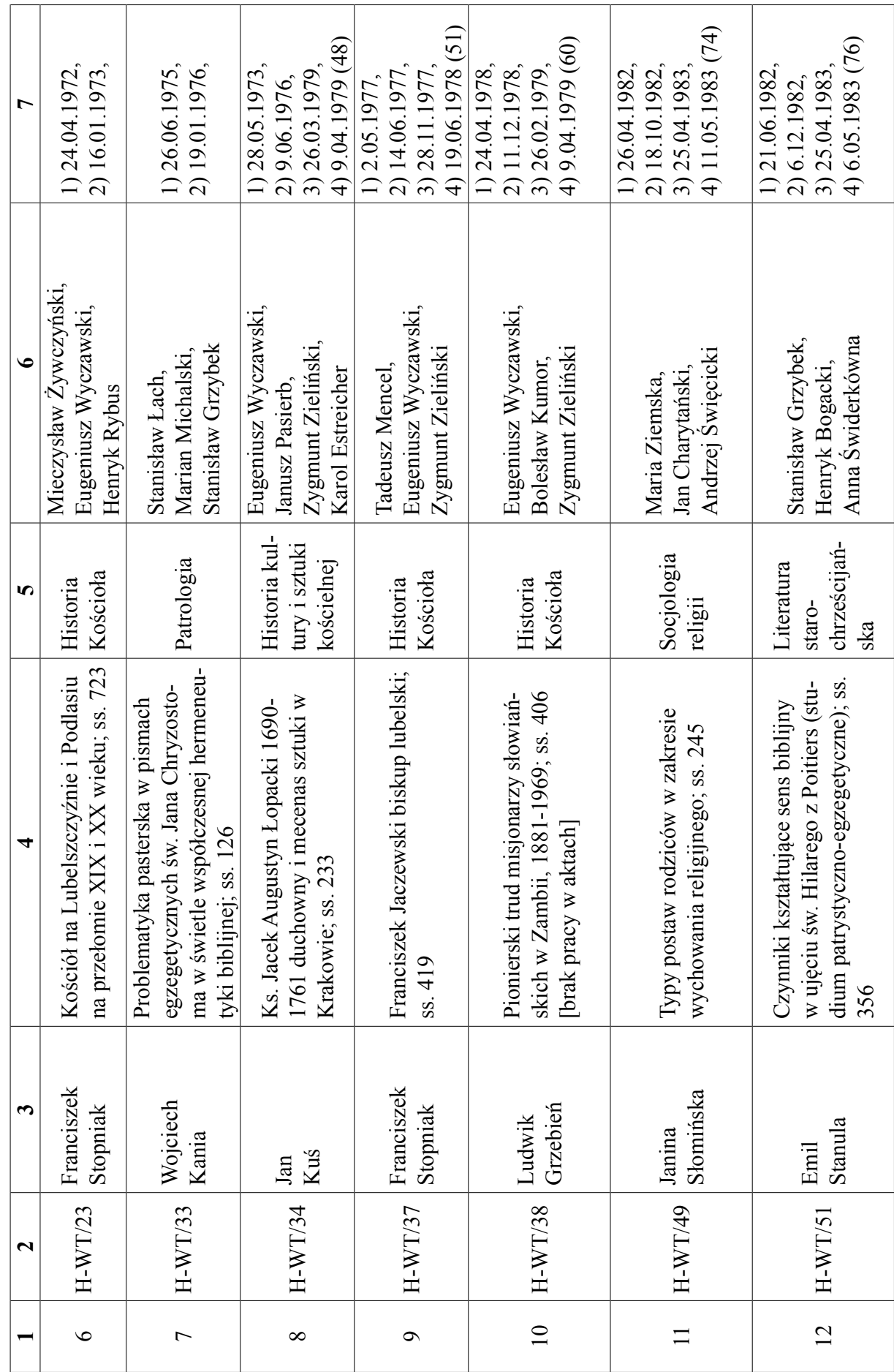




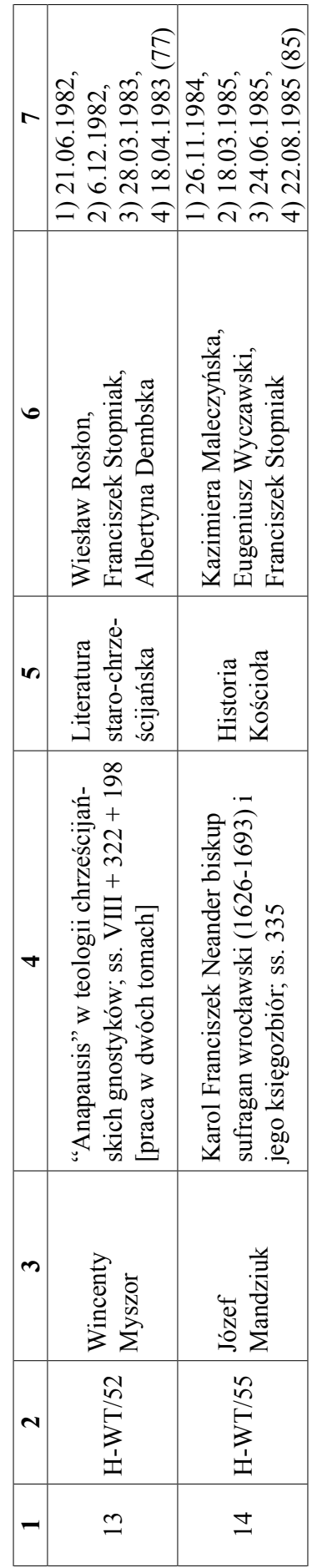




\section{BIBLIOGRAFIA}

\section{Źródla}

Archiwum UKSW

Akta osobowe Działu Kadr, sygn. DK-I/671

Akta przewodów doktorskich Wydziału Teologicznego sygn.: $6,8,9,13,16,19,25,33,39,43,44,45,46,47,49,59,60,66,68,77,79,81$, $82,84,85,88,89,92,93,94,101,102,103,107,108,109,112,117,118,119,123$, $129,132,135,138,143,151,152,157,158,160,161,167,170,174,175,176,194$, $198,200,217,221,222,225,236,240,242,245,258$

Akta przewodów habilitacyjnych Wydziału Teologicznego sygn.: H-WT/7, H-WT/8, H-WT/9, H-WT/19, H-WT/22, H-WT/23, H-WT/33, HWT/34, H-WT/37, H-WT/38, H-WT/49, H-WT/51, H-WT/52, H-WT/55

Protokoły z posiedzeń Rady Wydziału Teologicznego, sygn.: WT/11, WT/12, WT/13, WT/16, WT/17, WT/18, WT/20, WT/25, WT/31

\section{Opracowania}

Gołgowski Tadeusz, Archeologia starochrześcijańska, w: XX lat Akademii Teologii Katolickiej. Księga pamiątkowa 1954-1974, red. E. Wyczawski, Warszawa 1976, s. 173180.

Milewski Dariusz, Akta przewodów doktorskich i habilitacyjnych Wydziału Kościelnych Nauk Historycznych i Społecznych ATK, „Archiwa, Biblioteki i Muzea Kościelne”, 96 (2011) s. 39-56.

Milewski Dariusz, Pierwsze lata Archiwum Uniwersytetu Kardynała Stefana Wyszyńskiego w Warszawie - organizacja i funkcjonowanie, „Archiwa, Biblioteki i Muzea Kościelne", 93 (2010) s. 153-161.

Pasierb Janusz, Historia sztuki kościelnej, w: XX lat Akademii Teologii Katolickiej. Księga pamiątkowa 1954-1974, red. Eugeniusz Wyczawski, Warszawa 1976, s. 162-173

Stanula Emil, Patrologia, w: XX lat Akademii Teologii Katolickiej. Księga pamiątkowa 1954-1974, red. E. Wyczawski, Warszawa 1976, s. 148-162.

Wyczawski Eugeniusz, Historia Kościoła, w: XX lat Akademii Teologii Katolickiej. Księga pamiątkowa 1954-1974, red. E. Wyczawski, Warszawa 1976, s. 128-148. 


\title{
THE RECORDS OF REGISTRATION AND CONFERMENT PROCEDURE FOR A DOCTORATE AND HABILITATION IN HISTORICAL AND SOCIAL SCIENCES AT THE FACULTY THEOLOGY OF WARSAW THEOLOGICAL ACADEMY
}

\begin{abstract}
Summary
The article presents documentation, stored in the Archive of Cardinal Stefan Wyszyński University in Warsaw, concerning registration and conferment procedure for a doctorate and habilitation in historical and social sciences: history of the Church, history of church art, patrology, Christian archaeology, musicology, sociology of religion, Catholic social teaching and social ethics at the Faculty of Theology of Warsaw Theological Academy in the years 1954-1987. These records are part of the historical fonds (archival category: A) and are a valuable source on the history of educating academic staff at Warsaw Theological Academy. The article discusses the origins of documentation, including 69 archival units referring to registration and conferment procedure for a doctorate and 14 archival units concerning habilitation. The attached tables show the most important elements of each archival unit such as a reference number, the names of PHD students and those who obtained habilitation, their supervisors and reviewers, topics and the size of their works, the name of the specialty and the date of the most important resolutions concerning the procedure awarding a degree.
\end{abstract}

Keywords: registration and conferment procedure for a doctorate, registration and conferment procedure for habilitation, historical and social sciences, documentation, Warsaw Theological Academy, the Archive of Cardinal Stefan Wyszyński University 